\title{
Effects of Genotypes and Bagging Practice on Content of $\beta$-Carotene in Apple Fruits
}

\author{
Dongjie Jia \\ Qingdao Key Lab of Agriculture Quality \& Safety Engineering, College of Horticulture \\ Qingdao Agricultural University, 700 Changcheng Road, Chengyang, Qingdao 266109, China \\ Tel: 86-532-8803-0513Ｅ-mail: jdj1985@126.com
}

Lianmei Fan

Qingdao Key Lab of Agriculture Quality \& Safety Engineering, College of Life science Qingdao Agricultural University, 700 Changcheng Road, Chengyang, Qingdao 266109, China Tel: 86-532-8803-0513 E-mail: lianmeifan@163.com

Gengsen Liu

Qingdao Key Lab of Agriculture Quality \& Safety Engineering, College of Horticulture Qingdao Agricultural University, 700 Changcheng Road, Chengyang, Qingdao 266109, China

Tel: 86-532-8803-0513 E-mail: gsliu@qau.edu.cn

Junling Shen

Qingdao Key Lab of Agriculture Quality \& Safety Engineering, College of Horticulture Qingdao Agricultural University, 700 Changcheng Road, Chengyang, Qingdao 266109, China Tel: 86-532-8803-0513 E-mail: junling5541@163.com

Chenglian Liu

Qingdao Key Lab of Agriculture Quality \& Safety Engineering, College of Horticulture and Landscape Qingdao Agricultural University, Chengyang, Qingdao 266109, China

Tel: 86-532-8608-0330 E-mail: fmdb@qau.edu.cn

Yongbing Yuan (Corresponding author)

Qingdao Key Lab of Agriculture Quality \& Safety Engineering, College of Horticulture and Landscape Qingdao Agricultural University, Chengyang, Qingdao 266109, China

Tel: 86-532-8608-0018Ｅ-mail: yyb@qau.edu.cn

Received: February 9, 2011 Accepted: February 23, 2011 Published: December 1, 2011

doi:10.5539/jas.v3n4p196

URL: http://dx.doi.org/10.5539/jas.v3n4p196

The research is financed by China Agricultural Department No. 1440-2-1 and NSFC 30471200.

\begin{abstract}
$\beta$-Carotene content in apple fruits of different cultivars was determined by HPLC to provide some basic information for evaluating fruit quality and for controlling $\beta$-carotene of apples with orchard practices and biotechnology. Results showed that $\beta$-carotene content in apples was different with various cultivars and strains, orchard practices (bagging or not) and different parts (peel or flesh). $\beta$-Carotene content in Fuji Yanfu 3 was higher than Royal Gala and Tuscan. As to the same cultivar, Fuji, $\beta$-carotene content in Fuji Beni Shogun, an earlier maturation strain, was higher than Fuji Yanfu 3, a striped red color strain, and higher than Fuji Yanfu 6, a
\end{abstract}


blush red color strain. $\beta$-Carotene content of apple peel was usually higher than that of the flesh. $\beta$-Carotene content of the peel and flesh in Fuji Yanfu 3 apples was reduced by $30.43 \%$ and $4.38 \%$ respectively by paper bagging. It suggested that it is possible to produce higher $\beta$-carotene content apples with selected cultivars or strains and proper practices.

Keywords: Apple, $\beta$-Carotene, Carotenoids, Fruit bagging, HPLC

\section{Introduction}

$\beta$-Carotene is one of the antioxidants found widely in animals, plants and microorganisms, and has been recognized primarily for a biological function as a precursor for vitamin A. Numerous studies have demonstrated that $\beta$-carotene is an effective component with medicinal value relating to human health and has powerful functions such as anti-oxidation (Sergio et al., 1999), anti-irradiation (Umegaki et al., 1997; Wang et al., 2009), anti-tumor (Prakash et al., 2002; Prasad et al., 2006) and enhancement immunity (Chew et al., 2002). As food additives and dietary supplements, $\beta$-carotene is ascribed to the first class of nutritive pigment by $\mathrm{FAO} / \mathrm{WHO}$ JECFA.

Carotenoids embedded in the membranes of chloroplasts and chromoplasts constitute one of plant fat-soluble pigments and have high economic value for their colors with yellow, orange-red and red. Carotenoids have an ability to absorb and transfer electron as supplementary pigments in photosynthesis and play an important role in scavenging activity for chlorophyll triplet and superoxide radicals (Bartley et al., 1995; Tracewell et al., 2001).

$\beta$-Carotene is one of intermediate products in carotenoid biosynthesis. In recent years, certain progress has been made in manipulating genes involved in $\beta$-carotene biosynthesis by gene engineering techniques (Lamers et al., 2008; Rosati et al., 2000; Davison et al., 2002), such as increasing $\beta$-carotene content of fruits or converting $\beta$-carotene to zeaxanthin or other compounds of carotenoids in plants. However, the biochemical and molecular research on $\beta$-carotene biosynthesis of apples was very limited.

Apples with high nutrition value are recognized as "all-directional healthy fruits". In the present paper $\beta$-carotene content in apple fruits of some different cultivars and strains was determined by reversed-phase high performance liquid chromatography (HPLC) in order to provide some basic information for apple nutritional assessment and public nutrition selection and for controlling $\beta$-carotene content of apple fruits by improving the environmental conditions such as light and transferring $\beta$-carotene to other compounds of carotenoids by genetic engineering.

\section{Materials and Methods}

\subsection{Plant Materials}

Five apple cultivars and strains including Tuscan (green skin and white flesh), Royal Gala, Fuji Yanfu 3 (Fuji strain with striped red skin), Fuji Yanfu 6 (Fuji strain with blush red skin) and Fuji Beni Shogun (early mature Fuji strain with bright red skin and yellow flesh) were used to compare $\beta$-carotene content among different apple genotypes. Fuji Yanfu 3 was also employed to study the influence of paper bagging on $\beta$-carotene content. The bagging fruits were bagged five weeks after full bloom by double layer paper bags with red inner layer and outer layer with gray outside and black inside. The peel and flesh of commercial harvest apples were sampled separately with liquid nitrogen treatment and then stored in refrigerator at $-70^{\circ} \mathrm{C}$ waiting for assays of $\beta$-carotene and carotenoids.

\subsection{Chemicals}

All chemicals used were of analytical or HPLC grade. Ultra-pure water generated by the Milli-Q system was used. $\beta$-Carotene was purchased from Sigma. Working standard solution of $\beta$-carotene was prepared daily by diluting a stock solution of standard.

\subsection{Pigment Extraction}

$\beta$-Carotene and carotenoids were extracted from apple peel and flesh by the modified method of Wang (Wang et al., 1997). All extraction process was done in the dark or in subdued light. Apple peel and flesh samples from refrigerator at $-70^{\circ} \mathrm{C}$ were powered by freezing-grinder. Weighed sample powder $(15 \mathrm{~g})$ was extracted with acetone-petroleum ether $(20: 80)$ in an Erlenmeyer flasks with shaking at the constant temperature $\left(25^{\circ} \mathrm{C}\right)$ with $120 \mathrm{r} / \mathrm{min}$ for 1 hour and then extracted by ultrasonic for $20 \mathrm{~min}$. The suspensions were filtered on Buchner funnels following filter residue was washed by acetone until colorless and the combined filtrates were collected to separatory funnels with washing by $10 \% \mathrm{NaCl} \mathrm{3-4} \mathrm{times.} \mathrm{The} \mathrm{petroleum-ether} \mathrm{phases} \mathrm{were} \mathrm{separated} \mathrm{to}$ volumetric flasks with placing for 30 min by adding $30 \mathrm{~g} \mathrm{Na}_{2} \mathrm{SO}_{4}$ in the dark and evaporated to dry with RE-5285A rotary evaporator, then fixed to the volume of $5 \mathrm{ml}$ with chloroform. 


\subsection{HPLC Determination}

\subsubsection{Chromatographic Conditions}

The extracts obtained as described above were filtered through a $0.45 \mu \mathrm{m}$ membrane disc and were used to determine $\beta$-carotene by HPLC with an autosampler (injection volume, $20 \mu \mathrm{l}$ ) and Epslise XDB-C $\mathrm{C}_{18}$ column $(4.6 \times 150 \mathrm{~mm})$. The mobile phase was acetonitrile-methanol $(80: 20, \mathrm{v} / \mathrm{v})$; the flow-rate was $2.0 \mathrm{ml} / \mathrm{min}$; the column temperature was $40^{\circ} \mathrm{C}$ and chromatograms were monitored at $450 \mathrm{~nm}$. The column was regenerated by washing with methanol after analysis, and then equilibrated with the mobile phase. The system was characterized by rapid analysis, little interference and good repeatability. Chromatogram of standard was shown in Figure 2 and samples were shown in Figure 3 and Figure 4.

\subsubsection{Standard Curve}

$\beta$-Carotene standard stock solution was diluted to a series of concentrations at $1,3,5,8,10,15,20 \mu \mathrm{g} / \mathrm{ml}$ and they were detected with a injection of $20 \mu \mathrm{l}$ by HPLC. $\beta$-Carotene standard curve was illustrated in Figure 1. There was a good linear relationship between the peak area and the concentration with the equation of linear regression being $\mathrm{y}=10.473 \mathrm{x}-3.7749$ and the correlation coefficient being 0.9985 .

\subsubsection{Recoveries Analysis}

Five replicates of each of three cultivar samples were used to detect recovery rate. It can be seen from Table 1 that the recoveries of three samples with different $\beta$-carotene content were in the range of $93.30 \%-97.13 \%$.

\subsubsection{Detection Limit of $\beta$-Carotene}

The detection limit for $\beta$-carotene was $3.75 \times 10^{-8} \mathrm{~g}$ by measuring baseline and peak height of $\beta$-carotene standard solution with the concentration of $1 \mu \mathrm{g} / \mathrm{ml}$.

\subsection{Determination of Carotenoids Content with a Spectrophotometer}

The carotenoid content was measured with UV-2550 UV-Vis spectrophotometer (Lichenthaler et al., 1983). About $2 \mathrm{~g}$ of sample powder was weighed to Erlenmeyer flasks and there were 3 replicates in every sample. The petroleum-ether phases were evaporated to dry with rotary evaporator and fixed to $25 \mathrm{ml}$ by $80 \%$ acetone. The concentrations of the extracted total carotenoids were calculated from the absorbance values at $663 \mathrm{~nm}, 645 \mathrm{~nm}$, and $470 \mathrm{~nm}$ using equations described by Lichtenthaler:

where chlorophyll a $\mathrm{C}=12.21 \mathrm{~A}_{663 \mathrm{~nm}}-2.81 \mathrm{~A}_{645 \mathrm{~nm}}$;

chlorophyll b C=20.13 $\mathrm{A}_{645 \mathrm{~nm}}-5.03 \mathrm{~A}_{663 \mathrm{~nm}}$;

carotenoids $\mathrm{C}=\left(1000 \mathrm{~A}_{470 \mathrm{~mm}}-3.27 \mathrm{Chl}\right.$ a $\mathrm{C}-104 \mathrm{Chl}$ b C $) / 229$;

$\mathrm{A}=$ absorbance, $\mathrm{C}=$ pigment concentration $(\mu \mathrm{g} / \mathrm{ml}$ of extract $)$.

\subsection{Statistical Analysis}

The datas were statistically analyzed with SAS 8.0.

\section{Results}

\subsection{The Content of $\beta$-Carotene and Carotenoids in Apple Peel and Flesh of Different Cultivars and Strains}

Table 2 shows that there was a significant difference in the content of $\beta$-carotene and carotenoids of apple peel and flesh among various cultivars, Tuscan, Gala and Fuji, and among various strains of Fuji apples. Fuji Yanfu 3 with striped red skin and light yellow flesh color is the most important Fuji strain selected in Shandong Province, China and planted widely in China. Tuscan is a column apple cultivar with green skin and white flesh color. Gala is Royal Gala with blush red skin and yellow flesh. As to the tested cultivars, both contents of $\beta$-carotene (239.76 $\mu \mathrm{g} / 100 \mathrm{~g})$ and carotenoids $(457.73 \mu \mathrm{g} / 100 \mathrm{~g})$ in the skin of Fuji Yanfu 3 were higher than those of Gala (183.24 $\mu \mathrm{g} / 100 \mathrm{~g}$ and $284.28 \mu \mathrm{g} / 100 \mathrm{~g})$ and Tuscan $(68.96 \mu \mathrm{g} / 100 \mathrm{~g}$ and $270.53 \mu \mathrm{g} / 100 \mathrm{~g})$ and Gala higher than Tuscan in the contents of these pigments although carotenoids in the skin of Tuscan was very close to that of Gala. However, contents of $\beta$-carotene $(112.32 \mu \mathrm{g} / 100 \mathrm{~g})$ and carotenoids $(138.78 \mu \mathrm{g} / 100 \mathrm{~g})$ in the flesh of Fuji Yanfu 3 were slightly lower than those $(113.14 \mu \mathrm{g} / 100 \mathrm{~g}$ and $161.48 \mu \mathrm{g} / 100 \mathrm{~g})$ of Gala. The contents of $\beta$-carotene (23.17 $\mu \mathrm{g} / 100 \mathrm{~g})$ and carotenoids $(35.70 \mu \mathrm{g} / 100 \mathrm{~g})$ in the flesh of Tuscan were still lowest in the three cultivars.

As to the three strains of Fuji cultivar, Fuji Beni Shogun, an early maturity strain with yellow flesh and bright red skin, contained highest $\beta$-carotene $(390.41 \mu \mathrm{g} / 100 \mathrm{~g})$ and carotenoids $(576.38 \mu \mathrm{g} / 100 \mathrm{~g})$ while Fuji Yanfu 6, a blush red skin strain, contained lowest $\beta$-carotene $(90.66 \mu \mathrm{g} / 100 \mathrm{~g})$ and carotenoids $(260.73 \mu \mathrm{g} / 100 \mathrm{~g})$ in the peel. The contents of $\beta$-carotene $(326.75 \mu \mathrm{g} / 100 \mathrm{~g})$ and carotenoids $(412.52 \mu \mathrm{g} / 100 \mathrm{~g})$ in the flesh of Fuji Beni Shogun were also highest among the three strains of Fuji. Both contents of $\beta$-carotene $(76.80 \mu \mathrm{g} / 100 \mathrm{~g})$ and carotenoids 
$(96.78 \mu \mathrm{g} / 100 \mathrm{~g})$ in the flesh of Fuji Yanfu 6 were lower than those of other two strains. Fuji Yanfu 3 was moderate in the content of these pigments among three strains.

Although both contents of $\beta$-carotene and carotenoids in the flesh of Fuji Yanfu 6 and Tuscan were very low, their content of carotenoids in the skin were not as low as those in the flesh (Table 2).

\subsection{Effects of Bagging on Contents of $\beta$-Carotene and Carotenoids in Apples}

Fuji Yanfu 3, the most widely grown Fuji strain in China, was used to study the effects of bagging on the contents of $\beta$-carotene and carotenoids of apples. Table 3 shows that paper bag reduced greatly the content of $\beta$-carotene while it had less effect on carotenoids in the peel and on both $\beta$-carotene and carotenoids in the flesh of apples. The content of $\beta$-carotene in the peel of bagged fruits was decreased by $30.4 \%$ while carotenoids in the peel and both $\beta$-carotene and carotenoids in the flesh of bagged fruits were decreased only by $3.9 \%-5.8 \%$ in comparison with exposed fruits.

\section{Discussions}

Carotenoids comprise a large family of isoprenoids (Barkovich et al., 2001). $\beta$-Carotene is an important one of these pigments because of its position of precursor for vitamin A. The present results showed that there was a wide difference in the contents of $\beta$-carotene and carotenoids among apple cultivars, Tuscan, Gala and Fuji, and among various strains of Fuji. Within tested cultivars, the contents of $\beta$-carotene and carotenoids of Fuji Beni Shogun were highest and those of Tuscan were lowest, with the former being 5.66 and 2.13 times as the later in the peel, and 14.1 and 11.56 in the flesh, respectively. It was true in a similar difference even in the different strains of the same cultivar Fuji. This result implies that there is a big genetic potential for us to increase $\beta$-carotene content of commercial apples by selecting genotype. This is supported by other studies on carotenoids of fruits. Zhao et al. (2001) found that there was a significant difference in the content of carotenoids between Fuji and Red Delicious apples. After analyzing the carotenoid content of some traditional Portuguese fruits and vegetables, Dias et al. (2009) pointed that the carotenoid content of the analyzed items could vary with species, varieties, geographical place of production (region, site) and time of harvest. This cultivar specific in carotenoid concentration was also found in the changes of pigments during apple sunburn proceeding ( David et al., 2009). It is reasonable that yellow flower or fruit contains more carotenoids than white one (Murakami et al., 2004) since carotenoids makes the plant tissues yellow color. Present paper brought the same results that the deeper the yellow color, the higher the content of $\beta$-carotene and carotenoids in apple fruits.

Present result showed that $\beta$-carotene and carotenoids content of the peel was significantly higher than that of the flesh whereas the ratio of $\beta$-carotene to carotenoids of the peel $(0.25-0.68)$ was lower than that of the flesh $(0.65-0.81)$. It is especially true for the green cultivar, Tuscan, of which the ratio of $\beta$-carotene to carotenoids in the peel and flesh was 0.25 and 0.65 respectively. It was suggest that the content of some carotenoids other than $\beta$-carotene of peel was higher than that of the flesh. This is consistent with the fact that among total carotenoids, xanthophylls, lutein, violaxanthin and neoxanthin, are key components of the light-harvesting complexes of green tissues.

To all fruits analyzed this study there was a significant difference in the content of $\beta$-carotene and carotenoids of fruits between the peel and flesh of apples. The contents of $\beta$-carotene and carotenoids of the peel were 2.13 and 3.30 times as that of the flesh, respectively, in Fuji Yanfu 3, and 1.19 and 1.39, respectively in Shogun Fuji apples, an early mature mutation as well as considered a yellow flesh mutation in present paper. However, the times were 2.98 and 7.58 respectively in Tuscan, a green skin cultivar. It is postulated that the synthesis of carotenoids in fruits are separately between skin and flesh.

Paper bagging is widely used in apple production in China to make red skin color bright and to reduce chemicals residue. However it is always doubtful that bagging cover reduces apple quality. The present results showed that $\beta$-carotene content was reduced by $30.43 \%$ (1\% significance) in the peel but only by $4.38 \%$ ( $5 \%$ significance) in the flesh of Fuji apples by paper bagging as a common orchard practice. The total carotenoids content of the peel and flesh was reduced slightly by $5.81 \%$ (1\% significance) and $3.93 \%$ respectively by paper bagging. It was reported from previous studies that carotenoid content of fruits with bagging was always significantly lower than that of exposed apples (Wei et al., 2006; Xia et al., 2009; Tao et al., 2003). Lopez et al. (2003) found that $\beta$-carotene content of pimiento is higher in full sun compared with shaded treatments. Solovchenko et al. (2006) postulated that the difference in carotenoid content between sunlit and shading treatments was involved in ripening procedure in apples.

Carotenoids synthesized in organism are usually genetic control. However, the amount and types of carotenoids actually synthesized can be influenced by environmental factors including light intensity and quality, 
temperature and nutritional conditions. The exact mechanism on carotenoids pathway regulation by external factors still remains unknown although some compounds, such as $\beta$-carotene, lycopene, zeaxanthin, astaxanthin, of carotenoids pathway can be deliberately controlled by gene manipulation (Ralley et al., 2004; Sandmann, 2001).

Present results indicate that $\beta$-carotene and carotenoid content of some apple cultivars such as Fuji Beni Shogun is enough to provide the substance basis for controlling $\beta$-carotene biosynthesis gene expression and transformation to synthesis more some target compounds.

\section{References}

Bartley, G. E., \& Scolnik, P. A. (1995). Plant carotenoids: pigments for photoprotection, visual attraction and human health. Plant Cell, 7, 1027-1038.

Barkovich, R., \& Liao, J. C. (2001). Review, metabolic engineering of isoprenoids. Metabolic Engineering, 3, 27-39. http://dx.doi.org/10.1006/mben.2000.0168

Chew, B. P., Park, J. S., \& Wong, T. S. (2002). Dietary $\beta$-carotene stimulates cell-mediated and humeral immune response in dogs. J Nutr, 130, 1910-1913.

David, A. F., \& Larry, E. S. (2009). Changes in pigment concentrations associated with sunburn browning of five apple cultivars. I. Chlorophylls and carotenoids, Plant Science, 176, 78-83. http://dx.doi.org/10.1016/j.plantsci.2008.09.013

Davison, P. A., Hunter, C. N., \& Horton, P. (2002). Over expression of beta-carotene hydroxylase enhances the stress tolerance in Arabidopsis. Nature, 418, 203-206. http://dx.doi.org/10.1038/nature00861

Dharmapuri, S., Rosati, C., Pallara, P., Aquilani, R., Bouvier, F., Camara, B., \& Giuliano, G. (2002). Metabolic engineering of xanthophyll content in tomato fruits. FEBS Letter, 519, 30-34. http://dx.doi.org/10.1016/S0014-5793(02)02699-6

Dias, M. G., Filomena, M., Camões, G. F. C., \& Oliveira, L. (2009). Carotenoids in traditional Portuguese fruits and vegetables. Food Chemistry, 113, 808-815. http://dx.doi.org/10.1016/j.foodchem.2008.08.002

Lichenthaler, H. K., \& Wellburn, A. R. (1983). Determinations of total carotenoids and chlorophylls a and b of leaf extracts in different solvents. Biochem Soc Trans, 603, 591-592.

Lamers, P. P., Janssen, M., De Vos, R. C. H., Bino, R. J., \& Wijffels, R. H. (2008). Exploring and exploiting carotenoid accumulation in Dunaliella salina for cell-factory applications. Trends in Biotechnology, 26, 631-638. http://dx.doi.org/10.1016/j.tibtech.2008.07.002

Lopez, M., Candela, M. E., \& Sabater, F. (2003). Carotenoids from Capsicum annuum fruits: Influence of spectral quality of radiation. Biologia Plantarum, 28, 100-104. http://dx.doi.org/10.1007/BF02885203

Murakami, Y., Fukui, Y., Watanabe, H., Kokubun, H., Toya, Y., \& Ando, T. (2004). Floral coloration and pigmentation in Calibrachoa cultivars. J Horticultural Sci Biotechnol, 79, 47-53.

Prakash, P., Manfred, T. G., \& Jackson, C. L. (2002). $\beta$-Carotene alters the morphology of NCI-H69 small cell lung cancer cells. $J$ Nut, 132, 121-124.

Prasad, V., Chandele, A., Jagtap, J. C., Kumar, S., \& Shastry, P. (2006). ROS-triggered caspase2 activation and feedback amplification loop in beta-carotene induced apoptosis. Free Radic Bioi Med, 41, 418-421.

Ralley, L., Enfissi, E. M. A., Misawa, N., Schuch, W., Bramley P M, \& Fraser, P D. (2004). Metabolic engineering of ketocarotenoid formation in higher plants. The Plant Journal, 39, 477-486. http://dx.doi.org/10.1111/j.1365-313X.2004.02151.x

Rosati, C., Aquilani, R., Dharmapuri, S., Pallara, P., Marusic, C., Tavazza, R., Bouvier, F., \& Camara, B. (2000). Metabolic engineering of beta-carotene and lycopene content in tomato fruit. Plant J, 24, 413-419. http://dx.doi.org/10.1046/j.1365-313x.2000.00880.x

Sandmann, G. (2001). Genetic manipulation of carotenoid biosynthesis: strategies, problems and achievements. Trends Plant Sci., 6, 14-17. http://dx.doi.org/10.1016/S1360-1385(00)01817-3

Sergio, A. R., Paiva, M. D., \& Robert M. R. (1999). ß-Carotene and other carotenoids as antioxidants. Journal of the American College of Nutrition, 18, 426-433.

Solovchenko, A. E., Avertcheva, O. V., \& Merzlyak, M. N. (2006). Elevated sunlight promotes ripening-associated pigment changes in apple fruit. Postharvest Biology and Technology, 40, 183-189. http://dx.doi.org/10.1016/j.postharvbio.2006.01.013 
Tao, J., Zhang, S. L., An, X. M., \& Zhao, Z. Z. (2003). Effects of light on carotenoid biosynthesis and color formation of citrus fruit peel. Chinese Journal of Applide Ecology, 14, 1833-1836.

Tracewell, C. A., Vrettos, J. S., Bautista, J. A., Frank, H. A., \& Brudvig, G. W. (2001). Carotenoid photooxidation in photosystem II. Arch Biochem Biophys, 385, 61-69. http://dx.doi.org/10.1006/abbi.2000.2150

Umegaki, K., Uramoto, H., Suzuki, J., \& Esashi T. (1997). Feeding mice palm carotene prevents DNA damage in bone marrow and reduction of peripheral leukocyte counts, and enhances survival following X-ray irradiation. Carcinogenesis, 18, 1943-1947. http://dx.doi.org/10.1093/carcin/18.10.1943

Wang, J. J., Ma, A. G., Han, L., \& Shan, X.Z. (2009). Protective effect of $\beta$-carotene on rat with acute radiation damage. Acta academiae medicinae qing dao universitatis, 45, 416-418.

Wang, Q., Han, Y. S., \& Dai, Y. Q. (1997). Simultaneous determination of five carotenoids in tomato by reversed phase high performance liquid chromatography. Chinese J of chromatography, 15, 534-536.

Wei, J. M., Qi, X. D., Fan, C. ,H., \& Zhao, Z.Y. (2006). The effect of double-paper bag on the skin pigment, fruit sugar and acidity of red Fuji apple. Chinese Agricultural Science Bulletin, 22, 346-350.

Xia, J., Zhang, Z., Qu, S.C., Xu, C.C., \& Gao, J.J. (2009). Effects of bagging on the quality factors of Jiang Su Red Fuji apple in the process of growth and development. Jiangsu J. of Agr. Sci, 25, 351-356.

Zhao, W. E., Zhang, J. Q., Qiao, X. S., Yu, H., \& Han, Y. S. (2001). The determination of carotenoids in apple peel by HPLC. Journal of Fruit Science, 18, 95-97.

Table 1. Recoveries of external $\beta$-carotene of three apple samples

\begin{tabular}{|l|l|l|l|l|l|l|}
\hline \multicolumn{2}{|l|}{ Samples } & $\begin{array}{l}\beta \text {-Carotene } \\
\text { content } \\
\text { samples }(\mu \mathrm{g})\end{array}$ & $\begin{array}{l}\beta \text {-Carotene } \\
\text { adding }(\mu \mathrm{g})\end{array}$ & $\begin{array}{l}\text { Total } \beta \text {-carotene } \\
\text { content }(\mu \mathrm{g})\end{array}$ & Recovery (\%) & RSD (\%) \\
\hline \multirow{2}{*}{ Gala } & Peel & 39.53 & 40 & $78.07 \pm 0.40$ & $96.34 \pm 1.01$ & 0.52 \\
\cline { 2 - 7 } & Flesh & 21.14 & 40 & $60.00 \pm 0.34$ & $97.13 \pm 0.84$ & 0.56 \\
\hline $\begin{array}{l}\text { Fuji Yanfu } \\
3\end{array}$ & Peel & 37.48 & 40 & $75.51 \pm 0.45$ & $95.08 \pm 1.12$ & 0.60 \\
\cline { 2 - 7 } $\begin{array}{l}\text { Fuji Beni } \\
\text { Shogun }\end{array}$ & Flesh & 23.16 & 40 & $60.97 \pm 0.25$ & $94.53 \pm 0.64$ & 0.42 \\
\cline { 2 - 7 } & Feel & 77.59 & 40 & $114.91 \pm 0.75$ & $93.30 \pm 1.86$ & 0.65 \\
\hline
\end{tabular}

Table 2. Contents of $\beta$-carotene and carotenoids in apple peel and flesh of different cultivars and strains

\begin{tabular}{|l|l|l|}
\hline Samples & $\beta$-Carotene content $(\mu \mathrm{g} / 100 \mathrm{~g})$ & Carotenoids content $(\mu \mathrm{g} / 100 \mathrm{~g})$ \\
\hline Peel & & \\
\hline Tuscan & $68.96 \pm 0.88 \mathrm{e} \mathrm{E}$ & $270.53 \pm 7.91 \mathrm{~d} \mathrm{CD}$ \\
\hline RoyalGala & $183.24 \pm 1.16 \mathrm{c} \mathrm{C}$ & $284.28 \pm 1.18 \mathrm{c} \mathrm{C}$ \\
\hline Fuji Yanfu 3 & $239.76 \pm 4.94 \mathrm{~b} \mathrm{~B}$ & $457.73 \pm 4.51 \mathrm{~b} \mathrm{~B}$ \\
\hline Fuji Yanfu 6 & $90.66 \pm 0.33 \mathrm{~d} \mathrm{D}$ & $260.73 \pm 6.68 \mathrm{~d} \mathrm{D}$ \\
\hline Fuji Beni Shogun & $390.41 \pm 1.63 \mathrm{a} \mathrm{A}$ & $576.38 \pm 7.82 \mathrm{a} \mathrm{A}$ \\
\hline Flesh & & \\
\hline Tuscan & $23.17 \pm 0.58 \mathrm{~d} \mathrm{D}$ & $35.70 \pm 3.37 \mathrm{e} \mathrm{E}$ \\
\hline Gala & $113.14 \pm 0.92 \mathrm{~b} \mathrm{~B}$ & $161.48 \pm 7.63 \mathrm{~b} \mathrm{~B}$ \\
\hline Fuji Yanfu 3 & $112.32 \pm 3.60 \mathrm{~b}$ B & $138.78 \pm 2.62 \mathrm{c} \mathrm{C}$ \\
\hline Fuji Yanfu 6 & $76.80 \pm 0.51 \mathrm{c} \mathrm{C}$ & $96.78 \pm 8.63 \mathrm{~d} \mathrm{D}$ \\
\hline Beni Shogun & $326.75 \pm 4.82 \mathrm{a} \mathrm{A}$ & $412.52 \pm 1.25 \mathrm{a} \mathrm{A}$ \\
\hline SSR alys: “a
\end{tabular}

SSR analysis: "a" = Significant at 5\% level; "A" = Significant at $1 \%$ level

Table 3. Effects of bagging on contents of $\beta$-carotene and total carotenoids in apple peel and flesh

\begin{tabular}{|l|l|l|}
\hline \multicolumn{1}{|c|}{ Samples } & $\beta$-carotene content $(\mu \mathrm{g} / 100 \mathrm{~g})$ & Carotenoids content $(\mu \mathrm{g} / 100 \mathrm{~g})$ \\
\hline Peel & & \\
\hline Fuji Yanfu 3 (exposed) & $239.76 \pm 4.94 \mathrm{a} \mathrm{A}$ & $457.73 \pm 4.51 \mathrm{a} \mathrm{A}$ \\
\hline Fuji Yanfu 3 (bagging) & $166.79 \pm 0.70 \mathrm{~b}$ B & $431.13 \pm 1.69 \mathrm{~b}$ B \\
\hline Flesh & & \\
\hline Fuji Yanfu 3 (exposed) & $112.32 \pm 3.60 \mathrm{a} \mathrm{A}$ & $138.78 \pm 2.62 \mathrm{a} \mathrm{A}$ \\
\hline Fuji Yanfu 3 (bagging) & $107.40 \pm 0.57 \mathrm{~b} \mathrm{~A}$ & $133.33 \pm 4.29$ a A \\
\hline
\end{tabular}

SSR analysis: "a" = Significant at 5\% level; "A" = Significant at $1 \%$ level 


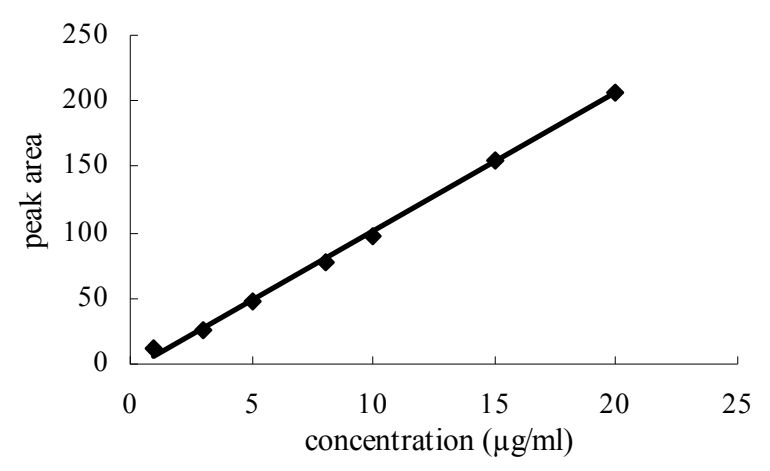

Figure 1. Standard curve of $\beta$-carotene by HPLC

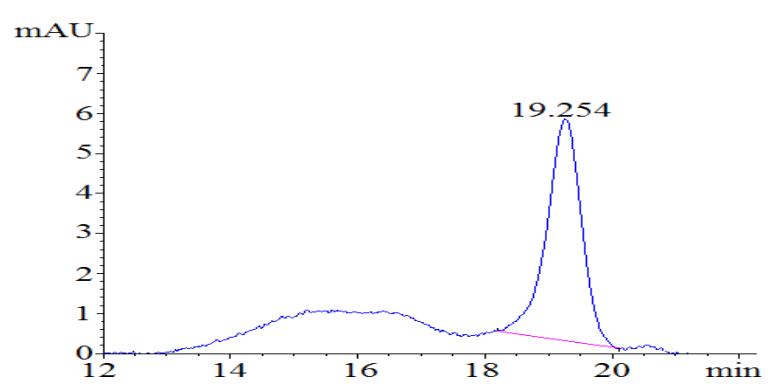

Figure 2. HPLC Chromatogram of standard

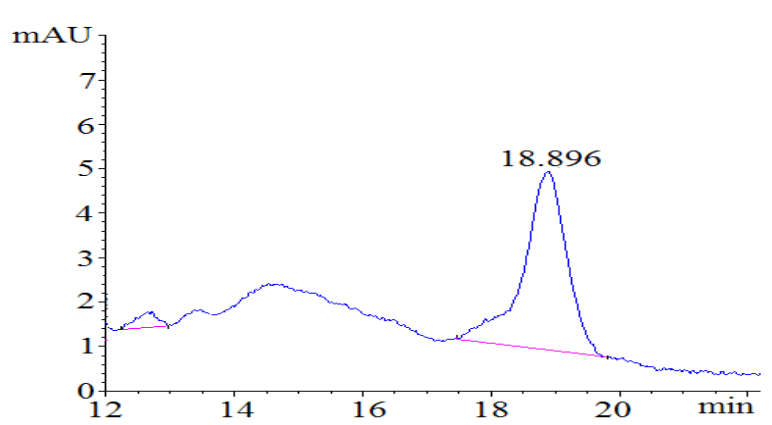

Figure 3. HPLC Chromatogram of $\beta$-carotene in the peel of apples

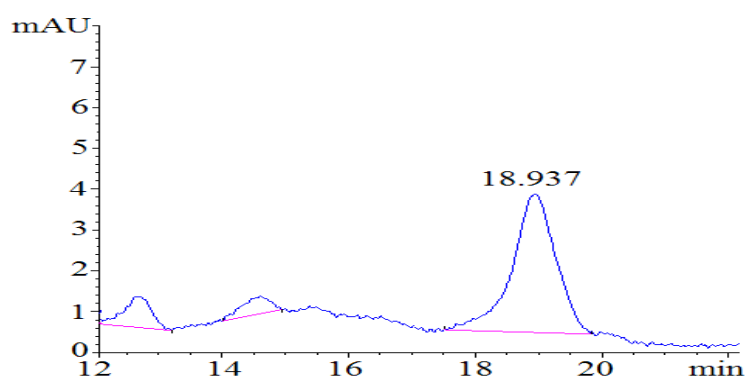

Figure 4. HPLC Chromatogram of $\beta$-carotene in the flesh of apples 